\title{
Psychological Well-Being, Gender Ideology, dan Waktu sebagai Prediktor Keterlibatan Ayah
}

\author{
Psychological Well-Being, Gender Ideology, and Time as \\ Predictors of Father Involvement
}

\author{
Cantyo Atindriyo Dannisworo ${ }^{1}$, Fadhilah Amalia ${ }^{2}$
}

1,2Fakultas Psikologi, Universitas Indonesia

\begin{abstract}
This study aimed to examine the role of psychological well-being, gender ideology, time spent together with children, and time spent at work in predicting father involvement. This study was conducted on fathers with at least one child aged 0-12 years old, who resided in Jakarta, Bogor, Depok, Tangerang, Bekasi (Jabodetabek). Data was collected from 371 fathers through online questionnaires. Results from multiple regression analysis suggest that psychological well-being $(\beta=0.322 ; p<0.01)$, gender ideology $(\beta=$ $0.104 ; p<0.05)$, and time spent with children $(\beta=0.126 ; p<0.05)$ significantly predicted father involvement $\left(R^{2}=0.145\right)$. Time spent at work $(\beta=0.014)$ however, did not predict father involvement. Though, there are other factors that need to be considered when we are going to predict father involvement, such as father's factors, mother's factors, child's factors, and contextual factors.
\end{abstract}

Keywords: father involvement; gender ideology; psychological well-being; working time

\begin{abstract}
Abstrak. Tujuan penelitian ini untuk melihat pengaruh psychological well-being, gender ideology, dan waktu, terhadap keterlibatan ayah. 'Waktu' di penelitian ini dioperasionalisasikan menjadi dua, yaitu waktu yang dihabiskan oleh ayah dan anak dan waktu kerja ayah. Penelitian dilakukan di Jakarta, Bogor, Depok, Tangerang, Bekasi (Jabodetabek), pada para ayah yang memiliki anak berusia 0-12 tahun. Pengambilan data mayoritas dilakukan secara daring, dan mendapatkan total sebanyak 371 partisipan. Hasil analisis multiple regression menunjukkan bahwa variabel-variabel yang telah disebutkan tadi dapat menjadi prediktor terhadap keterlibatan seorang ayah $\left(R^{2}=0,145\right)$. Tiga variabel, yaitu psychological well-being $(\beta=0,322 ; p<0,01)$, gender ideology $(\beta=0,104 ; p<0,05)$, waktu yang dihabiskan oleh ayah dengan anak $(\beta=0,126 ; p<0,05)$, dapat menjadi prediktor yang signifikan, sedangkan waktu kerja ayah $(\beta=0,014)$ tidak dapat memprediksi keterlibatan ayah. Meski begitu, masih banyak faktor-faktor yang perlu diperhatikan dan diukur ketika ingin memprediksi keterlibatan ayah di dalam pengasuhannya dengan anak.
\end{abstract}

Kata kunci: keterlibatan ayah; gender ideology; psychological well-being; waktu kerja

Masing-masing anggota keluarga memiliki peran yang berbeda satu sama lain. Berdasarkan pandangan tradisional, ayah berperan sebagai seorang kepala

\footnotetext{
${ }^{1}$ Korespondensi mengenai artikel ini dapat melalui: cantyo.dannis@ui.ac.id
}

keluarga, pemberi nafkah, pelindung, dan penjaga moral (Aryee \& Luk, 1996; Saraff \& Srivastava, 2010), sedangkan ibu mengurus pekerjaan-pekerjaan domestik seperti memasak, mencuci, membersihkan rumah, dan mengasuh anak (Aryee \& Luk, 
1996). Pengasuhan selalu diasumsikan sebagai tugas yang dimiliki oleh ibu, terutama di budaya patriarki (Freeman, 2008; Rohner \& Veneziano, 2001). Sejak tahun 1960-an, isu keterlibatan ayah dalam pengasuhan anak mulai menjadi pembahasan dan dianggap penting. Sekarang, peran, tanggung jawab, dan fungsi dari ayah di dalam pengasuhan dinilai sudah mulai berubah (Furstenberg Jr., 1995; Palkovitz, 2002). Terdapat peningkatan keterlibatan ayah, di mana Ibu yang awalnya mengambil peran utama dalam pengasuhan anak, kini sudah mulai membagi perannya tersebut dengan ayah (Maurer \& Pleck, 2006). Meskipun keduanya terlibat dalam interaksi dengan anak, Lamb (2010) berpendapat bahwa ibu dan ayah memiliki peran yang berbeda, yaitu ibu sebagai sosok yang mengasuh (bentuk-bentuk nurturing dan caretaking: memandikan, menyuapi, mengganti pakaian, dll) dan ayah memiliki spesialisasi sebagai teman bermain.

Di Amerika, sejak tahun 1965 hingga empat dekade berikutnya, waktu yang ayah habiskan dengan anak dan yang digunakan untuk mengerjakan pekerjaan rumah telah meningkat secara signifikan (Bianchi, Robinson, \& Milkie, 2006). Studi lain yang dilakukan oleh Smith (2009) menyatakan bahwa sejak tahun 1995 hingga 2007, jumlah ayah yang berada di rumah dan mengurus anak (stay at home dad) meningkat lebih dari dua kali lipat, dari 64.000 ayah menjadi 159.000 ayah. Angka tersebut belum termasuk para ayah yang bekerja, namun tetap mengurus urusan domestik. Di Indonesia juga sudah cukup banyak ayah yang secara nyata menunjukkan peran atau aktivitasnya dalam pengasuhan anak. Sebagai contoh, gerakan "ayah ASI" bertujuan untuk mendorong dan mendukung keterlibatan ayah dalam pengasuhan anak dan pemberian dukungan kepada ibu (Ali, 2015; Sewaka, 2017). Gerakan ini aktif dalam kampanye di sosial media hingga di penerbitan buku panduan bagaimana menjadi seorang "Ayah ASI". Selain itu, ada pula gerakan lain bernama "Bapak Rangkul" yang memiliki visi yang serupa (Zakiya, 2018).

Lamb (2010) mendefinisikan keterlibatan ayah sebagai seberapa besar peran aktif seorang ayah dalam kehidupan dan perkembangan anak. Hawkins dan Palkovitz (1999) mengatakan bahwa sejak sekitar tahun 1975, keterlibatan ayah hanya meliputi aspek-aspek yang dapat diobservasi saja. Oleh karena itu, keterlibatan ayah biasanya diukur dari interaksi langsung antara ayah dan anak serta kuantitas waktu yang ayah habiskan bersama dengan anak. Akan tetapi, peneliti-peneliti lain beranggapan bahwa keterlibatan ayah seharusnya juga diukur melalui dimensi-dimensi lain selain waktu yang dihabiskan dan bukan hanya mencakup perilaku yang dapat diobservasi saja (Palkovitz, 1997).

Keterlibatan ayah adalah sebuah konstruk multidimensional yang mencakup aspek afektif, kognitif, perilaku, dan etika (Hawkins \& Palkovitz, 1999). Hawkins et al. (2002) menambahkan bahwa perilaku tersebut tidak harus tampil secara langsung ketika bersama dengan anak, namun bisa juga tampil secara tidak langsung. Keterlibatan ayah dalam pengasuhan bukan hanya tentang bagaimana seorang ayah terlibat di dalam kehidupan anak kandungnya, ataupun anak tiri dan angkatnya. Keterlibatan ayah dalam pengasuhan adalah tentang bagaimana seorang ayah bertanggung jawab terhadap anak, bersedia masuk ke dalam dunia anak, merencanakan masa depan anak, memenuhi kebutuhan anak, menjaga dan membimbing anak, hingga 
kemauan mengembangkan anaknya menjadi individu yang dewasa dan matang (Palkovitz, 2002). Keterlibatan ayah dalam pengasuhan juga tentang bagaimana seorang ayah memberikan dukungan kepada ibu dari anak-anaknya dalam proses pengasuhan (Hawkins et al., 2002).

Banyak faktor yang memengaruhi keterlibatan ayah di dalam pengasuhan. Beberapa faktor yang dapat memengaruhi antara lain adalah: psychological well-being, gender ideology, dan waktu. Terkait dengan tingkat psychological well-being ayah, penelitian yang lalu menemukan bahwa ayah yang melakukan parental monitoring terhadap anaknya menunjukkan gejala depresi yang rendah (Caldwell, Bell, Brooks, Ward, \& Jennings, 2011; Coates \& Phares, 2014). Psychological well-being pada penelitian tersebut diukur melalui simtom depresif yang dialami oleh ayah. Hasilnya, ditemukan bahwa para ayah dengan simtom depresif lebih tinggi, memiliki tingkat monitoring yang lebih rendah pada anaknya $(\beta=-0,358, p<0,01)$. Coates dan Phares (2014) menyatakan bahwa psychological well-being dapat memprediksi keterlibatan ayah $(\beta=0,27, p<0,05)$. Penelitian lain yang dilakukan oleh Kotila dan Dush (2013) juga melihat hubungan keterlibatan ayah dengan psychological well-being, yang diukur melalui simtom depresif. Penelitian tersebut membedakan keterlibatan dan simtom depresif secara berkala, yaitu satu, tiga, dan lima tahun. Hasilnya, tingginya keterlibatan ayah diasosiasikan dengan rendahnya simtom depresif dalam jangka panjang. Selanjutnya, penelitian yang dilakukan pada ayah non-residential berkulit hitam menyatakan bahwa terdapat hubungan antara psychological well-being dan paternal involvement ( $r$ $=0,31, p<0,01)$ (Coates, 2012).
Di sisi lain, terdapat penelitian yang menunjukkan hasil yang sebaliknya. Penelitian menemukan bahwa ayah yang terlibat dalam pengasuhan diprediksi akan meningkatkan well-being ayah tersebut dan pengaruhnya dapat dirasakan dalam jangka waktu pendek hingga panjang (Schindler, 2007). Meski begitu, well-being ayah ternyata tidak dapat diprediksi untuk meningkatkan keterlibatan ayah terhadap pengasuhan. Penelitian lain juga menunjukkan hasil yang serupa. Wellbeing ayah ternyata tidak dapat memprediksi keterlibatannya dalam pengasuhan terhadap anak (Schindler, 2010). Penelitian yang dilakukan Coley dan Hernandez (2006) juga menemukan bahwa well-being ayah yang diukur melalui distress psikologis hanya dapat memprediksi keterlibatan pengasuhannya pada anak, pada sampel residential father namun tidak signifikan pada non-residential father. Hasil penelitian yang tidak konsisten ini, perlu dikaji kembali untuk melihat bagaimana pengaruh dan hubungan psychological wellbeing ayah dengan pengasuhannya terhadap anak.

Selain psychological well-being, kepercayaan individu terhadap maskulinitas tradisional juga dapat memengaruhi perilaku ayah terhadap anaknya (Caldwell, Antonakos, Tsuchiya, Assari, \& De Loney, 2013). Kepercayaan individu terhadap maskulinitas tradisional tersebut ini memiliki konsep serupa dengan gender ideology, yang didefinisikan oleh Levant dan Powell (2017) sebagai sebuah kepercayaan mengenai pentingnya laki-laki dan perempuan untuk mengikuti standar perilaku yang didefinisikan oleh masingmasing budaya. Penelitian menunjukkan (Bulanda, 2004; Evertsson, 2014) bahwa ayah yang memiliki ideologi gender yang lebih modern, akan lebih terlibat dalam pengasuhan anak. 
Selanjutnya, penelitian yang dilakukan oleh McGill (2014) mengukur keterlibatan ayah dalam pengasuhan anak melalui lima aspek yaitu: total waktu bersama anak $(R=17,3 p<0,01)$, physical care $(R=4,7 p<0,01)$, bermain $(R=8,5 p<$ $0,05)$, aktivitas pencapaian (achievement activities) $(R=0,6 p<0,01)$, dan tanggung jawab $(R=6,4 p<0,01)$. Secara umum, penelitian tersebut menemukan bahwa ayah yang memiliki sikap terhadap peran gender atau gender ideology yang nontradisional terhadap pengasuhan anak ditemukan menghabiskan waktu lebih banyak bersama dengan anak, lebih bertanggung jawab, dan lebih terlibat secara aktif dan bertanggung jawab terhadap anak. Hasil serupa juga ditemukan oleh Saraff \& Srivastava (2010) yang mengaitkan sikap atau gender ideology nontradisional terhadap keterlibatan ayah $(\beta=$ $-0,90 p<0,01)$. Penelitian lain, yang dilakukan oleh Karre (2015), ayah yang memiliki gender ideology yang lebih egalitarian, berkorelasi positif dengan keterlibatan ayah terhadap anaknya yang berusia remaja (memasuki masa perkuliahan), dengan korelasi $r=0,308(p<0,01)$. Selain itu, penelitian dari Makpal dan Adiyanti (2016) di Indonesia menujukkan hasil serupa, bahwa gender ideology dapat menjadi prediktor terhadap keterlibatan ayah.

Meski begitu, beberapa penelitian lain menunjukkan hasil yang berbeda. Hofferth dan Goldscheider (2010) menemukan bahwa ayah yang memiliki gender ideology atau gender role attitude tradisional justru lebih terlibat dibandingkan dengan ayah yang memiliki gender role attitude non-tradisional. Hasil serupa dari penelitian lain menemukan bahwa gender role ideology atau sex role attitude tidak dapat memprediksi keterlibatan seorang ayah terhadap anaknya (Crouter, Perry-
Jenkins, Huston, \& McHale, 1987; Meteyer \& Perry-Jenkins, 2010). Gaunt (2006) juga menemukan bahwa gender ideology tidak dapat memprediksi setiap dimensi dari keterlibatan ayah, yaitu direct care, responsibility, dan companion. Menurut Kuo, Volling, dan Gonzalez (2018), ideologi gender yang lebih egaliter hanya dapat memprediksi keterlibatan seorang ayah jika pasangannya juga bekerja dan mencari nafkah untuk keluarga. Hal ini menjadi menarik pada konteks budaya di Indonesia yang patriarki, di mana norma yang berlaku adalah laki-laki menjadi pencari nafkah utama dan perempuan tidak diharuskan untuk bekerja.

Selanjutnya, seperti yang sudah disampaikan sebelumnya, kritik dari Hawkins dan Palkovitz (1999) menyampaikan bahwa sejak awal mereka tidak setuju keterlibatan ayah hanya diukur dari waktu yang dihabiskan antara ayah dan anak saja. Oleh karena itu, beberapa penelitian mengenai keterlibatan ayah cukup banyak yang membandingkan antara resident father dengan non-resident father. Fokus dari penelitian-penelitian tersebut adalah untuk melihat perbedaan dampak dari adanya sosok ayah dan absennya sosok ayah di dalam kehidupan anak. Carlson, VanOrman, dan Turner (2017), menemukan bahwa resident father meluangkan waktu lebih banyak dibandingkan dengan non-resident father. Resident father juga memiliki keterlibatan yang lebih tinggi dibandingkan nonresident father, yang diukur melalui engagement dan tanggung jawab. Penelitian yang dilakukan oleh Kotila dan Dush (2013) mengukur perbedaan keterlibatan ayah pada resident dan non-resident father pada tiga tahun yang berbeda. Hasilnya menunjukkan bahwa terdapat perbedaan yang signifikan antara resident father dan nonresident father pada setiap tahunnya 
$\left(t_{1}(2701)=32,17 p<0,01 ; t_{2}(2391)=63,92 p<\right.$ 0,$\left.01 ; t_{3}(1854)=61,93 p<0,01\right)$. Castillo, Welch, dan Sarver (2011) dalam penelitiannya juga menemukan bahwa secara ratarata, resident father lebih terlibat dibandingkan dengan non-resident father. Penelitian tersebut juga menemukan bahwa terdapat hubungan yang negatif antara status residensi ayah terhadap keterlibatannya $(r=-0,46 ; p<0,01)$. Artinya, resident father lebih terlibat dengan anaknya dibanding non-resident father. Selanjutnya, penelitian oleh Bulanda (2004) menunjukkan bahwa waktu yang dihabiskan dengan anak dapat memprediksi keterlibatan seorang ayah $(\beta=6,11 p<0,01)$. Pengukuran menggunakan total waktu interaksi langsung ini jarang digunakan oleh penelitian-penelitian lain, tetapi peneliti menilai bahwa pengukuran ini lebih aplikatif dan dapat diberikan kepada populasi yang lebih luas, khususnya di Indonesia, baik kepada ayah yang masih tinggal bersama maupun yang tidak tinggal bersama.

Waktu yang dihabiskan ayah dalam bekerja juga menunjukkan hasil yang belum konsisten dalam memprediksi keterlibatan ayah. Ayah ditemukan masih menghabiskan waktu kerja yang lebih panjang dibanding dengan ibu dan menghabiskan waktu lebih sedikit dalam pengasuhan anak (Bianchi, 2011; Hill, 2005). Hal ini kemudian membuat ibu menjadi lebih banyak terlibat dalam pengasuhan anak. Temuan Bonney, Kelley, dan Levant (1999) juga menunjukkan bahwa waktu kerja ayah memengaruhi total waktu pengasuhan ayah dan keterlibatannya terhadap anak secara negatif. Di sisi lain Hofferth dan Goldscheider (2010) dalam penelitiannya menemukan bahwa ayah yang lebih sedikit menghabiskan waktu lebih dalam bekerja, memiliki keterlibatan yang lebih rendah pula. Kuo et al. (2018) juga menemukan bahwa waktu ayah bekerja tidak menjadi prediktor yang signifikan dalam memprediksi keterlibatan ayah. Pada penelitian ini, peneliti mengukur kehadiran sosok ayah di dalam kehidupan anak, yang dioperasionalisasikan melalui total waktu yang dihabiskan antara ayahanak dan total waktu kerja ayah.

Mulai banyaknya praktik-praktik keterlibatan ayah di dalam pengasuhan ini, tidak terlepas dari dampak positif yang muncul sebagai akibatnya. Allen dan Daly (2007) menyatakan bahwa secara umum keterlibatan ayah kepada anaknya dapat dilihat dari berbagai aspek, seperti kognitif, emosional, dan sosial. Pada anak usia sekolah, keterlibatan ayah dapat meningkatkan dorongan berprestasi, bersikap aktif dalam kegiatan sekolah (Flouri, Buchanan, \& Bream, 2002), dan memengaruhi prestasi akademik di sekolah (Jeynes, 2014). Dalam aspek emosional, keterlibatan ayah berpengaruh secara positif terhadap perkembangan kognitif, persepsi kompetensi diri (perceived competence), sense of social competence, dan kurangnya kemungkinan untuk mengalami depresi (Dubowitz et al., 2001; Lewin et al., 2014). Keterlibatan ayah juga berpengaruh positif pada perkembangan kompetensi sosial anak (Chae \& Lee, 2011; Torres, Veríssimo, Monteiro, Ribeiro, \& Santos, 2014), secara lebih spesifik yaitu kemampuan anak dalam menginisiasi relasi sosial (Stolz, Barber, \& Olsen, 2005). Selain itu, penelitian juga menunjukkan bahwa keterlibatan ayah memiliki hubungan dengan kepuasan pernikahan (Kwok, Ling, Leung, \& Li, 2012). Studi lain menemukan bahwa ayah yang lebih terlibat dalam pengasuhan anak dapat memengaruhi kesejahteraan istri, kepuasan pernikahan istri (Ramonetti, 2007) dan kualitas interaksi di 
dalam keluarga (Simonelli, Parolin, Sacchi, De Palo, \& Vieno, 2016).

Keterlibatan ayah tidak hanya berdampak pada anak dan istri, namun juga terhadap dirinya sendiri. Seorang laki-laki yang menjadi ayah, berkembang dan menjadi matang secara lebih positif dibanding dengan seorang laki-laki yang tidak terlibat secara aktif sebagai ayah (Palkovitz, 2002). Aspek yang berkembang antara lain adalah kognitif, sosial, emosional, kesehatan, kepribadian, dan karier. Hal ini disebabkan karena menjadi seorang ayah yang terlibat, memberikannya kesempatan, konteks, dan pengalaman yang kaya bagi dirinya untuk berkembang. Selanjutnya, ayah yang terlibat dalam pengasuhan akan mendapatkan banyak keuntungan lain, seperti kepuasan melihat anaknya tumbuh, rasa bangga, mendapatkan cinta, perkembangan diri, kesenangan, pembelajaran terus menerus di kehidupan, dan makna hidup (Palkovitz, 2002). Bahkan menurut Pollack (1995), menjadi ayah adalah pengalaman yang sangat berharga bagi laki-laki. Ia mengatakan "fathering is one of men's greatest opportunities for personal transformation".

Berdasarkan pemaparan di atas dan penelusuran peneliti, topik keterlibatan ayah di dalam pengasuhan masih minim diteliti di Indonesia. Hal ini mungkin disebabkan oleh masa peralihan dari peran ayah yang tradisional ke peran yang lebih modern. Selain itu, penelitian di Indonesia banyak yang lebih terfokus pada dampak keterlibatan ayah pada anak (Marsuq \& Kristiana, 2017; Septiani \& Nasution, 2017; Zuhairah \& Tatar, 2017) bukan pada faktor yang memprediksi keterlibatan ayah. Padahal, keterlibatan ayah pada anaknya dapat memberikan dampak yang positif terhadap berbagai pihak. Dari hasil penelitian dan temuan terkait prediktor keterlibatan ayah yang mayoritas dilakukan di berbagai negara, dapat disimpulkan bahwa terdapat beberapa faktor yang dapat memengaruhi keterlibatan ayah, yaitu: psychological wellbeing, gender ideology, dan waktu. Meski begitu, pengaruh dari masing-masing variabel ini masih menunjukkan hasil yang tidak konsisten. Oleh karena itu, peneliti ingin melihat bagaimana pengaruh dari variabel-variabel tersebut berperan menjadi prediktor dari keterlibatan ayah. Oleh karena itu, pertanyaan pada penelitian ini adalah "Apakah psychological well-being, gender ideology, waktu ayah dengan anak, dan waktu kerja ayah dapat memprediksi keterlibatan ayah?".

\section{Metode}

\section{Partisipan}

Partisipan didapatkan melalui penyebaran informasi terbuka melalui media sosial, dengan menggunakan metode nonprobability sampling, yaitu teknik accidental sampling. Partisipan yang terlibat dalam penelitian ini yaitu dengan kriteria: lakilaki, memiliki anak dengan rentang usia 012 tahun, dan berdomisili di Jabodetabek. Terdapat sebanyak 416 partisipan yang mengisi kuesioner secara daring dan 2 partisipan secara luring. Dari seluruh responden tersebut, terdapat 28 partisipan yang tidak berasal dari wilayah Jabodetabek sehingga terdapat total 371 partisipan yang sesuai dengan kriteria untuk kemudian diolah dan dianalisis datanya. Seluruh partisipan diberikan beberapa pertanyaan terkait demografis dan tiga alat ukur. Dari 371 partisipan, usia terendah adalah 21 tahun dan tertinggi adalah 53 tahun, dengan mean usia yaitu 33,6 tahun. Dilihat dari segi penghasilan, $48 \%$ dari para ayah yang terlibat dalam penelitian memiliki pengha- 
silan per bulan lebih dari Rp10.000.000. sedangkan $48 \%$ lainnya memperoleh penghasilan antara Rp3.000.000Rp10.000.000. Terdapat 0,3\% ayah yang tidak berpenghasilan dan 3,8\% ayah yang memiliki penghasilan di bawah Rp3.000.000. Selanjutnya, dari segi pendidikan, $83,6 \%$ partisipan adalah lulusan jenjang Sarjana. Terdapat pula satu orang ayah yang berpendidikan SMP dan satu orang yang berpendidikan Doktoral.

\section{Instrumen dan pengukuran}

\section{Keterlibatan ayah}

Inventory of Father Involvement (IFI) yang dikembangkan oleh Hawkins et al., (2002), mengukur sembilan faktor dari keterlibatan ayah, yaitu: (i) Discipline and Responsibility, (ii) School Encouragement, (iii) Mother Support, (iv) Providing, (v) Time and Talking Together, (vi) Praise and Affection, (vii) Developing Talents, (viii) Reading/ Homework Support, dan (ix) Attentiveness. Alat ukur ini terdiri dari 26 item, dengan panduan pertanyaan "Seberapa baik saudara melakukan tugas sebagai seorang ayah", pilihan jawaban berskala Likert dari 0 (sangat tidak baik) sampai 6 (sangat baik sekali). Partisipan juga disediakan pilihan jawaban PTS (Pertanyaan Tidak Sesuai). Sehingga jika pernyataan yang ada dirasa tidak sesuai dengan kondisi yang dialaminya, ia diperbolehkan untuk mengisi pilihan jawaban tersebut. Alat ukur IFI telah diadaptasi untuk kepentingan penelitian ini $(\alpha=0,945)$. Contoh dari item pada alat ukur ini adalah (13) "Mengatakan kepada anak Anda, bahwa Anda mencintainya" dan (24) "Menghabiskan waktu dengan anak Anda untuk melakukan kegiatan yang mereka sukai". Pada alat ukur ini karena partisipan diperbolehkan mengisi PTS pada item yang dianggap tidak sesuai dengan keadaannya, maka data (jumlah item) yang terisi dari setiap partisipan dapat berbeda. Oleh karena itu, peneliti mengambil rata-rata skor dari alat ukur tersebut. Misalnya partisipan mengisi hanya 20 dari 26 item, maka untuk mendapatkan rata-rata perhitungan yang dilakukan adalah dengan menjumlahkan total skor partisipan lalu dibagi 20. Oleh karena itu, skor rata-rata terendah pada alat ukur ini adalah 0 dan tertinggi adalah 6. Semakin tinggi skor rata-rata yang didapat oleh partisipan, maka semakin tinggi keterlibatan ayahnya.

\section{Gender ideology}

Selanjutnya, alat ukur IPSPC (Cunningham, 2008) untuk mengukur gender ideology. Adaptasi ke dalam Bahasa Indonesia telah dilakukan untuk penelitian ini $(\alpha=0,866)$. Alat ukur ini terdiri dari 6 item, dengan pilihan jawaban berskala likert dari 1 (sangat tidak setuju) hingga 5 (sangat setuju). Skor terendah adalah 6 dan skor tertinggi adalah 30 . Semakin tinggi skor gender ideology, maka semakin ia menganggap bahwa peran gender di masyarakat seharusnya setara. Sebaliknya, semakin rendah skor yang didapat, maka semakin ia menganggap bahwa peran gender di masyarakat tidak setara atau memiliki perannya masingmasing yang berbeda. Contoh item pada alat ukur ini adalah: (2) "Ada pekerjaan untuk laki-laki dan ada juga untuk perempuan, dan mereka sebaiknya tidak saling mengerjakan yang bukan pekerjaannya" dan (5) "Akan lebih baik bagi semua orang jika lakilaki menjadi pencari nafkah utama bagi keluarga dan perempuan mengurus rumah serta keluarga".

\section{Psychological well-being}

Alat ukur terakhir, Psychological Well-Being (PWB), yang dikembangkan oleh Ryff (Ryff, 1989; Ryff \& Keyes, 1995), mengukur 
beberapa dimensi, antara lain: selfacceptance, positive relationship with others, autonomy, environmental mastery, purpose in life, serta personal growth. Pada penelitian ini, alat ukur PWB yang digunakan diambil dari penelitian yang telah dilakukan oleh Ednadita (2013). Peneliti kemudian melakukan tryout dan uji reliabilitas kembali $(\alpha=0,804)$, karena populasi penelitian yang diteliti berbeda. Secara keseluruhan, alat ukur ini berisi 18 item, dengan pilihan jawaban dari 1 (sangat tidak setuju) hingga 6 (sangat setuju). Skor terendah adalah 18 dan skor tertinggi adalah 108. Semakin tinggi skor pada alat ukur PWB, maka semakin tinggi pula psychological well-being individu tersebut. Contoh dari item alat ukur ini antara lain: (6) "Ketika saya melihat kembali hidup saya, saya puas dengan apa yang telah terjadi" dan (8) "Tuntutan hidup sehari-hari sering membuat saya tertekan".

\section{Prosedur}

Pada tahap awal, peneliti melakukan studi literatur mengenai keterlibatan ayah, gender, dan juga kesejahteraan psikologis. Di samping itu, juga dilakukan studi bagaimana peranan ayah yang terjadi pada usia anak 0-12 tahun. Hasil studi literatur tersebut kemudian dijadikan dasar untuk melakukan persiapan terhadap alat ukur yang akan digunakan, yaitu Inventory of Father Involvement, Gender Ideology, dan Psychological Well-Being. Pada awalnya, dilakukan proses alih bahasa (back to back translation), face validity, dan uji keterbacaan dengan expert judgment. Kemudian, proses adaptasi dilakukan dengan melakukan uji coba terhadap ketiga alat ukur tersebut dengan menyebarkan kuesioner secara manual dan daring kepada 43 partisipan. Selanjutnya, data uji coba tersebut dianalisis dan dilakukan uji reliabilitas. Setelah menda- patkan hasil try out, dilakukan revisi beberapa item yang ada pada alat ukur IFI dan PWB, untuk kemudian dapat digunakan pada proses pengambilan data field.

Pada tahapan pelaksanaan, peneliti melakukan penyebaran kuesioner secara daring melalui aplikasi seperti Whatsapp, Line, Twitter, dan Instagram. Partisipan diminta untuk mengisi ketiga alat ukur serta pertanyaan singkat terkait data demografis disebarkan secara daring. Peneliti juga menyebarkan beberapa kuesioner secara luring. Pada kuesioner luring, partisipan diminta untuk menandatangani informed consent sebelum mengisi kuesioner. Sedangkan untuk partisipan yang mengisi kuesioner secara daring, partisipan akan diberikan pertanyaan terkait ketersediaan untuk mengikuti penelitian ini dan dipersilahkan untuk klik "next" jika bersedia. Pada tahap berikutnya, peneliti melakukan screening kriteria pada data yang didapatkan. Selanjutnya, dilakukan proses analisis secara statistik menggunakan program SPSS.

\section{Desain penelitian dan analisis data}

Penelitian ini adalah penelitian noneksperimental, karena tidak ada manipulasi terhadap variabel dan partisipan penelitian. Penelitian ini juga merupakan penelitian korelasional, yang melibatkan lebih dari dua variabel yang diteliti, yaitu keterlibatan ayah, psychological well-being, dan gender ideology. Ketiga alat ukur tersebut kemudian skornya masingmasing diukur untuk mengidentifikasi bagaimana pola keterhubungan dari variabel-variabel yang terukur tersebut. Pengambilan data penelitian dilakukan pada satu waktu, sehingga penelitian ini dapat dikategorikan sebagai penelitian cross-sectional. Penelitian ini sudah disetujui oleh tim kaji etik Fakultas Psikologi Universitas Indonesia. Data yang sudah 
didapatkan, dianalisis menggunakan program SPSS 23.0. Teknik analisis statistik yang digunakan dalam penelitian ini adalah Multiple Regression. Teknik ini digunakan untuk melihat peran Gender Ideology, Psychological Well-Being, Waktu Ayah dengan Anak, dan Waktu Kerja Ayah untuk memprediksi Keterlibatan Ayah.

\section{Hasil}

Mean dari alat ukur keterlibatan ayah adalah 4,749 $(S D=0,734)$, mean dari alat ukur Gender Ideology adalah 20,57 (SD = 4,68), dan mean dari alat ukur Psychological Well-Being adalah 83,91 (SD = 9,236). Selanjutnya, rata-rata waktu yang dihabiskan oleh ayah dan anak dalam satu hari adalah 4,74 jam $(S D=3,66)$, sedangkan mean waktu kerja dalam satu minggu adalah 41,28 jam $(S D=18,82)$. Selanjutnya, berdasarkan hasil analisis korelasi, terlihat bahwa terdapat hubungan yang signifikan antara keterlibatan ayah dengan variabel lain yaitu gender ideology, psychological wellbeing, dan waktu ayah-anak. Hubungan lain yang signifikan juga adalah antara gender ideology dengan psychological wellbeing dan waktu ayah-anak. Di sisi lain, waktu kerja ayah selama satu minggu, tidak memiliki hubungan yang signifikan terhadap variabel lain.
Hasil analisis multiple regression yang dilakukan menunjukkan bahwa model yang diajukan untuk memprediksi keterlibatan ayah ini terbukti signifikan $(F(4,366)=15,563 p<0,01)$. Faktor-faktor pada model regresi ini, yaitu Psychological Well-Being, Gender Ideology, Waktu Ayah dengan Anak, dan Waktu Ayah Bekerja, secara bersamaan dapat menjelaskan $14,5 \%$ varians pada keterlibatan ayah (adjusted $R^{2}=0,136$ ).

Berdasarkan Tabel 2., terlihat bahwa terdapat tiga variabel yang dapat menjadi prediktor signifikan terhadap keterlibatan seorang ayah. Ketiga variabel tersebut adalah Waktu Ayah-Anak, Gender Ideology, dan Psychological Well-Being. Waktu AyahAnak menjadi salah satu prediktor yang signifikan terhadap keterlibatan ayah $(\beta=$ $0,126, p<0,05)$. Artinya, semakin sering ayah menghabiskan waktu dengan anaknya, maka semakin tinggi pula kemungkinannya untuk dapat terlibat dengan anak. Sedangkan, lamanya waktu ayah bekerja tidak menjadi prediktor yang signifikan untuk keterlibatannya di dalam pengasuhan dengan anak $(\beta=0,014 ; p>$ $0,05)$. Dengan demikian, meskipun seorang ayah menghabiskan waktu yang sangat banyak untuk bekerja, selama ia dapat menyisihkan waktu, maka ia akan tetap dapat terlibat dengan anaknya.

Tabel 1.

Korelasi Antar Variabel

\begin{tabular}{lccccc}
\hline \multicolumn{1}{c}{ Prediktor } & $\begin{array}{c}\text { Keterlibatan } \\
\text { Ayah }\end{array}$ & $\begin{array}{c}\text { Gender } \\
\text { Ideology }\end{array}$ & $\begin{array}{c}\text { Psychological } \\
\text { Well-Being }\end{array}$ & $\begin{array}{c}\text { Wakyu Ayah - Anak } \\
\text { (dalam jam/hari) }\end{array}$ & $\begin{array}{c}\text { Waktu Kerja Ayah } \\
\text { (dalam jam/minggu) }\end{array}$ \\
\hline $\begin{array}{l}\text { Keterlibatan Ayah } \\
\text { Gender Ideology }\end{array}$ & 1 & $.145^{* *}$ & 1 & & \\
$\begin{array}{l}\text { Psychological Well-Being } \\
\text { Waktu Ayah - Anak }\end{array}$ & $.342^{* *}$ & $.093^{*}$ & 1 & 1 \\
$\begin{array}{l}\text { (dalam jam/hari) } \\
\begin{array}{l}\text { Waktu Kerja Ayah } \\
\text { (dalam jam/minggu) }\end{array}\end{array}$ & $.160^{*}$ & $.088^{*}$ & .082 & -.081 & 1 \\
\hline$* 0.05 * * 0.01$ & .040 & .031 & &
\end{tabular}


Variabel selanjutnya, yaitu Psychological Well-Being, juga menjadi prediktor yang signifikan terhadap keterlibatan ayah $(\beta=0,322 ; p<0,01)$. Artinya, jika ayah memiliki psychological well-being yang tinggi, maka ia juga akan semakin terlibat dengan anak-anaknya. Prediktor yang signifikan berikutnya adalah gender ideology $(\beta=0,104 ; p<0,05)$. Signifikansi pada variabel ini menunjukkan bahwa semakin ayah menganggap peran gender antara laki-laki dan perempuan setara, maka ia akan semakin terlibat dengan anaknya.

Tabel 2.

Hasil Analisis Regresi Faktor-Faktor terhadap Keterlibatan Ayah

\begin{tabular}{lccc}
\hline \multicolumn{1}{c}{ Prediktor } & B & SE & $\beta$ \\
\hline Waktu Ayah - Anak & .025 & .010 & $.126^{*}$ \\
Waktu Kerja Ayah & .001 & .002 & .014 \\
Gender Ideology & .016 & .008 & $.104^{*}$ \\
Psychological Well-Being & .026 & .004 & $.322^{* *}$
\end{tabular}

Note. $\mathrm{R}^{2}=.145, \mathrm{~F}(4,366)=15.563, \mathrm{p}<.000$.

${ }^{*} p<0.05$

** $p<0.01$

\section{Diskusi}

Hipotesis awal penelitian ini mengacu pada pendapat Hawkins dan Palkovitz (1999) yang menyatakan bahwa keterlibatan ayah tidak hanya dapat dilihat berdasarkan waktu yang dihabiskan oleh ayah dengan anak saja. Berdasarkan analisis yang telah dilakukan, tampak bahwa keterlibatan ayah tidak hanya dipengaruhi oleh satu faktor saja, namun dipengaruhi oleh beberapa faktor. Keterlibatan ayah tidak hanya dipengaruhi oleh waktu yang dihabiskan oleh ayah dan anak, namun juga oleh gender ideology dan psychological well-being. Meski begitu, hasil ini kembali menegaskan bahwa waktu yang dihabiskan di antara ayah dan anak juga masih menjadi faktor yang penting dan signifikan untuk memprediksi keterlibatan seorang ayah. Jika melihat setiap variabelnya, psychological well-being menjadi variabel yang paling berperan dalam memprediksi keterlibatan ayah, diikuti oleh waktu ayah-anak, kemudian gender ideology.

Hasil penelitian ini secara umum mendukung penelitian-penelitian sebelumnya yang menyatakan bahwa psychological well-being (Caldwell et al., 2011; Coates \& Phares, 2014; Coates, 2012; Kotila \& Dush, 2013) dapat menjadi faktor penting yang dapat memengaruhi keterlibatan ayah. Berbeda dengan penelitianpenelitian sebelumnya yang mengukur psychological well-being dengan melihat ada atau tidaknya gejala depresif pada seorang ayah, pada penelitian ini, psychological wellbeing diukur secara langsung dengan alat ukur psychological well-being yang dikembangkan oleh Ryff (1989). Sehingga, diharapkan alat ukur ini dapat menggambarkan secara lebih akurat kesejahteraan psikologis seseorang.

Selanjutnya, penelitian-penelitian sebelumnya membandingkan keterlibatan ayah antara resident dan non-resident father dan menemukan bahwa resident father lebih terlibat (Carlson et al., 2017; Castillo et al., 2011; Kotila \& Dush, 2013). Mayoritas partisipan pada penelitian ini tinggal bersama dengan anaknya, sehingga penelitian ini menilik resident father lebih mendalam dan mengidentifikasi faktorfaktor yang dapat memprediksi keterlibatannya dalam pengasuhan anak. Penelitian ini mencoba untuk mengidentifikasi faktor waktu secara konkrit dan terukur sebagai prediktor keterlibatan ayah, yaitu waktu yang dihabiskan interaksi ayah-anak dan waktu kerja ayah. Hasil terkait waktu kerja ayah ini sejalan 
dengan penelitian di DKI Jakarta (Partasari, Lentari, \& Priadi, 2018) dan Amerika Serikat (Kuo et al., 2018) yaitu tidak terdapat hubungan yang signifikan antara waktu kerja ayah dengan keterlibatan ayah. Selain itu, penelitian ini juga memperkaya informasi terkait dengan variabel gender ideology yang masih jarang diteliti di Indonesia.

Hasil penelitian ini dapat menjadi dasar teoretis untuk mengembangkan strategi-strategi untuk program promosi tentang bagaimana seorang ayah dapat menjadi semakin terlibat dengan anakanaknya sesuai konteks budaya di Indonesia. Terlebih, seperti yang sudah dijelaskan, penelitian keterlibatan ayah di Indonesia dari sisi ayah masih sangat minim. Ketiga faktor, yaitu psychological well-being, gender ideology, dan waktu menjadi hal yang penting untuk dilibatkan ketika ingin mengembangkan keterlibatan seorang ayah. Ayah harus dapat fokus dengan dirinya terlebih dahulu, agar bisa membuat dirinya lebih sejahtera secara psikologis. Setelah itu, ia baru dapat mulai terlibat dengan anak-anaknya. Pendekatan teoretis lain yang dapat dilakukan untuk membuat ayah terlibat adalah dengan menggunakan perspektif gender. Para ayah dapat diberikan pemahaman atau psikoedukasi terkait bagaimana peran dari laki-laki dan perempuan yang lebih setara dalam kehidupan bermasyarakat. Diharapkan, setelah memiliki pemahaman yang baik mengenai pembagian peran yang setara ini, laki-laki atau ayah, dapat mulai terlibat di dalam pengasuhan dengan anak-anaknya. Strategi pada dua faktor ini perlu dilakukan sedini mungkin kepada laki-laki yang akan menjadi seorang ayah. Jika strategi promosi tersebut baru dilakukan setelah individu tersebut menjadi seorang ayah, maka mungkin akan terlambat. Padahal, anak sudah memerlukan sosok ayahnya sejak ia masih sangat kecil. Ditambah lagi, jika pandangan mengenai peran laki-laki dan perempuan di masyarakat baru ditanamkan setelah dewasa, maka akan menjadi lebih menantang untuk mengubahnya. Mengingat sosialisasi peran gender sudah dilakukan oleh masyarakat sejak individu tersebut masih sangat kecil. Selain itu, dari faktor waktu menunjukkan bahwa sesibuk apapun pekerjaan seorang ayah, ia dapat menyisihkan waktunya untuk berinteraksi dengan anak-anaknya, karena waktu yang dihabiskan bersama menjadi salah satu faktor penting untuk membangun keterlibatan ayah dengan anak.

Partisipan pada penelitian ini mayoritas didapatkan melalui penyebaran kuesioner secara daring. Hal ini membuat kebanyakan partisipan adalah para individu yang memiliki pendidikan dan akses internet yang baik. Dari seluruh data yang didapatkan, 83,6\% partisipan memiliki tingkat pendidikan S1 ke atas. Selain itu, secara penghasilan, $48 \%$ partisipan memiliki penghasilan Rp10.000.000. ke atas setiap bulannya. Data-data ini menggambarkan bahwa metode pengambilan sampel yang dilakukan pada penelitian ini masih terbatas pada populasi dengan karakteristik tingkat sosial ekonomi atas. Data sampel pada tingkat pendidikan dan penghasilan yang rendah tidak terlalu tergambar. Padahal, tingkat pendidikan dan status ekonomi akan memengaruhi persepsi individu terhadap keterlibatannya dengan anak (Bronte-Tinkew, Carrano, \& Guzman, 2006), yang kemudian akan memengaruhi perilakunya pula. Penelitian Caldwell et al., (2011) yang melihat hubungan antara parental monitoring dengan status ekonomi menunjukkan bahwa para ayah dengan status ekonomi lebih rendah, menunjukkan tingkat monitoring yang lebih tinggi 
dibanding ayah dengan status ekonomi tinggi $(\beta=-0,137, p<0,05)$. Instabilitas secara finansial pada seorang ayah juga dapat memengaruhi keterlibatan seorang ayah dengan anaknya secara negatif (Goldberg, Tan, Davis, \& Easterbrooks, 2013). Meski menunjukkan hasil yang kontradiktif, kedua penelitian tersebut menunjukkan bahwa terdapat pengaruh dari status ekonomi terhadap keterlibatan ayah.

Keterbatasan selanjutnya adalah tidak adanya pembatasan dari peneliti terhadap usia ayah sebagai partisipan. Karakteristik sampel pada penelitian ini adalah laki-laki yang memiliki anak berusia 0 hingga 12 tahun, tidak ada batas usia untuk ayah tersebut. Usia terendah dari salah satu partisipan adalah 21 tahun dan tertinggi adalah 53 tahun. Usia yang tidak dikontrol ini mungkin dapat memengaruhi berbagai variabel lainnya. Salah satu penyebabnya adalah bahwa para partisipan yang mengisi kuesioner penelitian ini mungkin berada pada tahap perkembangan yang berbeda menurut Erikson. Erikson (1977) mengatakan bahwa setiap individu memiliki tugas perkembangan yang berbeda pada setiap tahapan usia. Pada kasus ini, seorang ayah yang berusia 21 tahun memiliki tahap perkembangan yang berbeda dengan seorang ayah yang berusia 53 tahun. Ayah yang berusia 21 tahun memiliki tugas perkembangan identity ws role confusion, yang artinya ia masih fokus terhadap pencarian identitas dirinya. Sedangkan ayah yang berusia 53 tahun memiliki tugas perkembangan generativity vs stagnation. Pada tahap tersebut, fokusnya adalah membantu dan membesarkan generasi di bawahnya. Jika melihat perbedaan usia pada sampel partisipan penelitian ini, mungkin terdapat juga perbedaan pengalaman individu dalam pengasuhan. Hal ini juga akan memengaruhi tentang bagaimana individu mempersepsi dan berperilaku terhadap keterlibatannya dengan anak. Hal ini didukung oleh temuan dari Castillo et al., (2011) yang menyatakan bahwa ayah yang lebih tua, memiliki keterlibatan yang lebih tinggi dengan anaknya. Selain itu, keterlibatan ayah maupun ibu, akan semakin berkurang seiring dengan bertambahnya usia anak (Phares, Fields, \& Kamboukos, 2009).

Selain tidak adanya pembatasan terhadap usia ayah, peneliti juga tidak membatasi urutan kelahiran anak dan usia saudara anak selain yang 0 hingga 12 tahun tersebut. Misalnya, seorang ayah memiliki satu atau lebih anak berusia 0 hingga 12 tahun, mungkin juga memiliki anak lain yang berusia di atas 12 tahun. Jumlah anak dan perbedaan tahapan perkembangan anak ini menurut Doherty, Kounesky, dan Erickson (1998) juga dapat memengaruhi keterlibatan ayah. Selanjutnya, pada penelitian ini jenis kelamin anak tidak dibatasi. Kriteria partisipan penelitian hanyalah seorang ayah yang memiliki anak berusia 0 - 12 tahun, tanpa memperhatikan jenis kelamin. Padahal, jenis kelamin anak sangat mungkin memengaruhi persepsi dan perilaku keterlibatan dirinya dengan anak. Hasil penelitian menyatakan bahwa Ayah lebih terlibat dengan anak laki-lakinya, dibanding dengan anak perempuannya (BronteTinkew et al., 2006; Wood \& Repetti, 2004). Hal ini disebabkan karena mungkin ayah lebih mengidentifikasikan dirinya kepada anak yang memiliki jenis kelamin sama dengannya.

Di samping itu, tidak ada pula kontrol pada usia anak, di mana peneliti menggunakan rentang usia yang cukup besar, yaitu 0-12 tahun. Anak pada usia tertentu memiliki tahapan perkembangan yang berbeda dan kebutuhan akan pengasuhan 
yang berbeda-beda pula (Santrock, 2015). Pada usia 0-1 tahun (infant), umumnya ibu sangat banyak terlibat dalam proses pengasuhan, seperti menyusui, memandikan anak dan lain-lain. Sedangkan, keterlibatan ayah pada usia tersebut umumnya masih pada aktivitas bermain dengan anak (Lamb, 2000). Pada usia early childhood, salah satu tahapan perkembangan anak adalah berkaitan dengan peran gender. Pada tahapan ini, keterlibatan ibu lebih banyak pada anak perempuannya dan begitu pula ayah yang lebih banyak memperhatikan anak laki-lakinya untuk mengembangkan fungsi peran sebagai laki-laki (Santrock, 2015). Pada usia middle and late childhood, tugas anak mulai berkembang pada tanggung jawab sekolah dan juga membentuk pertemanan (Santrock, 2015). Di tahap ini, orang tua terlibat dalam hal bagaimana mengembangkan kemampuan anak untuk lebih bertanggung jawab pada peran dan tugastugasnya. Orang tua berperan penting dalam keterlibatannya sebagai manajer untuk memfasilitasi anak untuk berkesempatan berlatih dan juga mengawasi perilaku anak, salah satunya dalam konteks lingkungan sosial. Selanjutnya, usia anak pada penelitian ini dibatasi hingga usia 12 tahun, karena setelah usia tersebut, anak sudah mulai terpisah dan membagi perhatian dan waktunya kepada teman-temannya. Palkovitz (2002) mengatakan bahwa seiring dengan perkembangan anak, ia akan membutuhkan tingkat dan jenis keterlibatan dari ayah yang berbeda-beda.

Penelitian ini hanya mengukur perspektif dari sisi ayah saja dan tidak dari perspektif ibu. Padahal, terdapat literatur (Hofferth, Pleck, Stueve, Bianchi, \& Sayer, 2002) yang meragukan akurasi laporan keterlibatan ayah ini. Meski begitu, terdapat pula literatur yang mengatakan bahwa laporan ayah mengenai keterlibatannya ini dapat dianggap reliabel dan akurat (Wical \& Doherty, 2005). Argumenargumen yang berbeda ini menjadi perhatian peneliti dalam menginterpretasi data yang didapatkan. Pada penelitian ini, waktu yang dihabiskan oleh ayah bersama dengan anak, yaitu sebanyak 4,74 jam per hari. Penelitian Hofferth et al. (2002) menyatakan bahwa rata-rata waktu yang dihabiskan oleh ayah bersama dengan anak setiap harinya berkisar antara 3 hingga 4,5 jam. Jika dibandingkan dengan penelitian lain di India (Saraff \& Srivastava, 2010), ayah hanya melaporkan bahwa ia menghabiskan waktu sebanyak 2,8 jam setiap harinya. Waktu yang dihabiskan ayah di dalam penelitian ini berada di atas rata-rata dua penelitian di atas. Perbedaan ini juga mungkin disebabkan bahwa Ayah dalam penelitian ini hanya melaporkan perkiraan waktu berapa lama ia menghabiskan waktu dengan anak, namun bukan waktu sebenarnya. Misalnya saja, dalam satu kesempatan bersama anak, Ayah mungkin saja sedang melakukan kegiatan lain untuk dirinya sendiri, seperti makan, mandi, ke toilet, dan lain-lain. Sehingga 4,74 jam tersebut, tidak secara aktual menggambarkan 4,74 jam aktivitas bersama, tetapi ada saat di mana ia pergi meninggalkan anaknya.

Di samping itu, terdapat penelitian yang menyebutkan bahwa maternal encouragement atau dorongan dari istri terhadap suaminya juga dapat menjadi prediktor yang signifikan terhadap keterlibatan ayah dalam pengasuhan (SchoppeSullivan, Brown, Cannon, Mangelsdorf, \& Sokolowski, 2008). Penelitian tersebut juga menjelaskan bahwa maternal encouragement juga dapat menjadi mediator untuk kualitas coparenting. Sejalan dengan hal tersebut, penelitian dari Pleck dan 
Hofferth (2008) menemukan bahwa keterlibatan seorang ibu dalam pengasuhan juga dapat menjadi prediktor keterlibatan ayah di dalam pengasuhan. Tidak hanya dukungan, namun keyakinan seorang istri (mother's belief) terhadap peran suaminya sebagai ayah, menjadi variabel yang memediasi keterlibatan ayah dengan anak (McBride et al., 2005). Penelitian-penelitian ini menunjukkan, bahwa peran ibu dalam hubungannya terhadap keterlibatan sangatlah penting, sehingga perlu diperhitungkan pula.

\section{Kesimpulan}

Keterlibatan ayah di dalam pengasuhan mulai berkembang sejak tahun 1960-an. Cukup banyak faktor yang dapat memengaruhi keterlibatan ayah ini, tiga di antaranya yang diprediksi memiliki pengaruh cukup besar adalah psychological well-being, gender ideology, dan waktu. Variabel waktu dalam penelitian ini dioperasionalisasikan dengan (1) waktu yang dihabiskan oleh ayah bersama dengan anak dan (2) waktu kerja ayah. Hasil dari penelitian ini menunjukkan bahwa psychological well-being, gender ideology, dan waktu yang dihabiskan oleh ayah bersama dengan anak, menjadi prediktor yang signifikan terhadap keterlibatan ayah. Sedangkan waktu kerja ayah, tidak memiliki pengaruh yang signifikan terhadap keterlibatan ayah. Model ini menjelaskan 14,5\% dari varians keterlibatan ayah dalam pengasuhan. Hasil penelitian ini diharapkan dapat membantu para ayah untuk fokus pada kesejahteraan psikologisnya terlebih dahulu sebelum dapat terlibat dalam pengasuhan. Hasil ini juga menunjukkan bahwa intervensi untuk meningkatkan keterlibatan ayah dapat dilakukan dengan perspektif gender. Ayah diharapkan dapat memahami kesetaraan dalam pembagian peran di keluarga, sebelum akhirnya menjadi lebih terlibat. Selain itu, ayah juga dapat menyisihkan waktu bersama dengan anak, seberapapun sibuknya ia bekerja. Di sisi lain, masih banyak faktor lain yang dapat menjadi prediktor keterlibatan ayah, antara lain adalah: faktor individu ayah, faktor ibu, faktor kontekstual, dan faktor anak.

\section{Saran}

Penelitian berikutnya perlu mempertimbangkan metode pengambilan sampel yang bisa mendapatkan data dari berbagai lapisan masyarakat. Seperti yang sudah disampaikan di atas, penelitian ini membutuhkan data sampel dari individuindividu yang memiliki penghasilan dan pendidikan yang rendah. Penelitian berikutnya bisa melakukan pengambilan data tidak hanya secara daring, namun juga perlu melakukannya secara luring ke lapangan. Selanjutnya, penelitian mengenai keterlibatan ayah juga perlu melibatkan ibu sebagai salah satu variabel. Seperti yang telah dijelaskan, ayah seringkali menilai tinggi keterlibatannya dengan ayah. Oleh karena itu, pelibatan ibu ini penting dilakukan agar peneliti dapat melakukan cross-check secara objektif terhadap persepsi ayah terkait pengasuhannya.

Hasil penelitian ini menunjukkan bahwa tiga dari empat variabel yang diukur, yaitu psychological well-being, gender ideology, dan waktu ayah bersama anak, dapat memprediksi keterlibatan seorang ayah dengan anaknya sebesar $14,5 \%$. Penelitian berikutnya perlu mempertimbangkan variabel-variabel lainnya yang dinilai berpengaruh terhadap keterlibatan ayah. Doherty et al. (1998) menyatakan bahwa tingkat keterlibatan ayah dengan anak dipengaruhi oleh faktor ayah (asal keluarga dan status pekerjaan), 
faktor ibu (sikap terhadap pengasuhan ayah, ekspektasi, dan dukungan ayah), faktor kontekstual (ras atau etnis, ekspektasi budaya, dan dukungan sosial), faktor anak (usia, jenis kelamin, temperamen, perkembangan anak, pemaknaan dan kepercayaan terhadap pengasuhan ayah), dan hubungan orang tua (status pernikahan, kooperasi, dan dukungan mutual). Faktor-faktor tersebut dapat menjadi faktor yang dapat diukur untuk penelitian berikutnya.

\section{Kepustakaan}

Ali, F. (2015). Komunitas ayah ASI minta masyarakat dukung aktivitas ibu menyusui. Diunduh pada 15 Januari 2018, dari https://megapolitan.kompas. com/read/2015/09/19/05580071/Komun itas.Ayah.ASI.Minta.Masyarakat.Duku ng.Aktivitas.Ibu.Menyusui

Allen, S., \& Dally, K. (2007). The effects of father involvement: An updated research summary of the evidence. Guelph. Diunduh dari https://library. parenthelp.eu/wp-content/uploads/ 2017/05/Effects of Father Involvement.pdf

Aryee, S. \& Luk, V. (1996). Balancing two major parts of adult life experience: Work and family identity among dualearner couples. Human Relations, 49(4), 465-487.

Bianchi, S. M. (2011). Family change and time allocation in American families. Annals of the American Academy of Political and Social Science, 638, 21-44. doi: $\underline{10.1177 / 0002716211413731}$

Bianchi, S. M., Robinson, J. P., \& Milkie, M. A. (2006). The changing rhythms of American family life. New York: Russell Sage Foundation.
Bonney, J. F., Kelley, M. L., \& Levant, R. F. (1999). A model of fathers' behavioral involvement in child care in dual-earner families. Journal of Family Psychology, 13. Diunduh dari https://search.proquest. com/docview/614367406/fulltextPDF/2 15499B0C20045ABPQ/9?accountid=172 42

Bronte-Tinkew, J., Carrano, J., \& Guzman, L. (2006). Resident fathers' perceptions of their roles and links to involvement with infants. Fathering, 4(3), 254-285.

Bulanda, R. E. (2004). Paternal involvement with Children: The Impact of gender ideologies. Journal of Marriage and Family, 66(1), 40-45. doi: 10.1111/j.0022-2455.2004.00003.x

Caldwell, C. H., Antonakos, C. L., Tsuchiya, K., Assari, S., \& De Loney, E. H. (2013). Masculinity as a moderator of discrimination and parenting on depressive symptoms and drinking behaviors among nonresident AfricanAmerican fathers. Psychology of Men and Masculinity, 14(1), 47-58. doi: $\underline{10.1037 / \mathrm{a} 0029105}$

Caldwell, C. H., Bell, L., Brooks, C. L., Ward, J. D., \& Jennings, C. (2011). Engaging nonresident african american fathers in intervention research: What practitioners should know about parental monitoring in nonresident families. Research on Social Work Practice, 21(3), 298-307. doi: $\underline{10.1177 / 1049731510382923}$

Carlson, M. J., VanOrman, A. G., \& Turner, K. J. (2017). Fathers' investments of money and time across residential contexts. Journal of Marriage and Family, 79, 10-23. doi: 10.1111/jomf.12324

Castillo, J., Welch, G., \& Sarver, C. (2011). Fathering: The relationship between fathers' residence, fathers' sociodemographic characteristics, and father 
involvement. Maternal and Child Health Journal, 15, 1342-1349. doi: 10.1007/ $\underline{\text { s10995-010-0684-6 }}$

Chae, J. Y., \& Lee, K. Y. (2011). Impacts of Korean fathers' attachment and parenting behavior on their children's social competence. Social Behavior and Personality, 39(5), 627-644. doi: $\underline{10.2224 / \mathrm{sbp} .2011 .39 .5 .627}$

Coates, E. E. \& Phares, V. (2014). Predictors of paternal involvement among nonresidential, black fathers from low-income neighborhoods. Psychology of Men and Masculinity, 15(2), 138-151. doi: 10.1037/a0032790

Coates, E. E. (2012). Overcoming adversity: Resilience of low-income, nonresidential, black fathers. University of South Florida. Diambil dari https://scholarcommons.usf.edu/cgi/vi ewcontent.cgi?referer=https://www.go ogle.co.id/\&httpsredir $=1 \&$ article $=5210$ \&context=etd

Coley, R. L., \& Hernandez, D. C. (2006). Predictors of paternal involvement for resident and nonresident low-income fathers. Developmental Psychology, 42(6), 1041-1056. doi: 10.1037/0012$\underline{1649.42 .6 .1041}$

Crouter, A. C., Perry-Jenkins, M., Huston, T. L., \& McHale, S. M. (1987). Processes underlying father involvement in dual-earner and single-earner families. Developmental Psychology, 23(3), 431-440. doi: 10.1037/0012$\underline{1649.23 .3 .431}$

Cunningham, M. (2008). Influences of gender ideology and housework allocation on women's employment over the life course. Social Science Research, 37(1), 254-267. doi: 10.1016/ j.ssresearch.2007.01.003

Doherty, W. J., Kouneski, E. F., \& Erickson, M. F. (1998). Responsible fathering: An overview and conceptual framework. Journal of Marriage and the Family, 60(2), 277-292. doi: $\underline{10.2307 / 353848}$

Dubowitz, H., Black, M. M., Cox, C. E., Kerr, M. A., Litrownik, A. J., Radhakrishna, A., ... Runyan, D. K. (2001). Father involvement and children's functioning at age 6 years: A multisite study. Child Maltreatment, $6(4), \quad 300-309 . \quad$ doi: $\underline{10.1177 /}$ 1077559501006004003

Ednadita, G. (2013). Perbedaan psychological well-being antara lansia pemilik dan nonpemilik hewan peliharaan. Skripsi (tidak dipublikasikan). Jakarta: Universitas Indonesia.

Erikson, E. H. (1977). Childhood and society. London: Paladin Grafton Books. doi: 10.1007/s10856-007-0140-3

Evertsson, M. (2014). Gender ideology and the sharing of housework and child care in Sweden. Journal of Family Issues, 35(7), 927-949. doi: $\underline{10.1177 /}$ $\underline{0192513 \times 14522239}$

Flouri, E., Buchanan, A., \& Bream, V. (2002). Adolescents' perceptions of their fathers' involvement: Significance to school attitudes. Psychology in The Schools, 39(5), 575-582. doi: 10.1002/pits.10055

Freeman, T. (2008). Psychoanalytic concepts of fatherhood: Patriarchal paradoxes and the presence of an absent authority. Studies in Gender and Sexuality, 9(2), 113-139. doi: $\underline{10.1080 / 15240650801935156}$

Furstenberg Jr., F. F. (1995). Dealing with dads: The changing roles of fathers. In P. L. Chase-Lansdale \& J. BrooksGunn (Ed.), Escape from poverty: What makes a difference for poor children? (hal. 189-210). New York: Cambridge University Press. 
Gaunt, R. (2006). Biological essentialism, gender ideologies, and role attitudes: What determines parents' involvement in child care. Sex Roles, 55, 523533. doi: $10.1007 / \mathrm{s} 11199-006-9105-0$

Goldberg, W. A., Tan, E. T., Davis, C. R., \& Easterbrooks, M. A. (2013). What predicts parental involvement by young fathers at psychosocial risk? Fathering, 11(3), 280-291. doi: $\underline{10.3149 / \mathrm{fth} .1103 .280}$

Hawkins, A. J., Bradford, K. P., Palkovitz, R., Christiansen, S. L., Day, R. D., \& Call, V. R. A. (2002). The inventory of father involvement: A pilot study of a new measure of father involvement. The Journal of Men's Studies, 10(2), 183196.

Hawkins, A. J., \& Palkovitz, R. (1999). Beyond ticks and clicks: The need for more diverse and broader conceptualizations and measures of father involvement. The Journal of Men's Studies, 8(1), 11-32.

Hill, E. J. (2005). Work-family facilitation and conflict, working fathers and mothers, work-family stressors and support. Journal of Family Issues, 26(6), 793-819. doi: $\underline{\text { 10.1177/019 }}$ 2513X05277542

Hofferth, S. L. ;, \& Goldscheider, F. (2010). Does change in young men's employment influence fathering? Family Relations, 59(4), 479-493. doi: 10.1111/j.1741-3729.2010.00617.x

Hofferth, S. L., Pleck, J. H., Stueve, J. L., Bianchi, S., \& Sayer, L. (2002). The demography of fathers: What fathers do. In C. S. Tamis-LeMonda \& N. Cabrera (Ed.), Handbook of father involvement: Multidisciplinary perspective (hal. 63-90). New Jersey: Lawrence Erlbaum Associates.
Jeynes, W. H. (2014). A meta-analysis: The relationship between father involvement and student academic achievement. Urban Education, 50(4), 387-423. doi: 10.1177/ $\underline{0042085914525789}$

Karre, J. (2015). Gender-based attitudes and father involvement: Amount, assessment, and desires for more. Fathering, 13(3), 231-244.

Kotila, L. E., \& Dush, C. M. K. (2013). Involvement with children and lowincome fathers' psychological wellbeing. Fathering, 11(3), 306-326. doi: $\underline{10.3149 / \text { fth. } 1103.306}$

Kuo, P. X., Volling, B. L., \& Gonzalez, R. (2018). Gender role beliefs, workfamily conflict, and father involvement after the birth of a second child. Psychology of Men and Masculinity, 19(2), 243-256. doi: 10.1037/ $\underline{\text { men0000101 }}$

Kwok, S. Y. C. L., Ling, C. C. Y., Leung, C. L. K., \& Li, J. C. M. (2012). Fathering self-efficacy, marital satisfaction and father involvement in Hong Kong. Journal of Child and Family Studies, 22(8), 1051-1060. doi: 10.1007/s10826012-9666-1

Lamb, M. E. (2000). The histroy of research on father involvement. Marriage and Family Review, 29, 2-3, 23-42. doi: $\underline{10.1300 / J 002 v 29 n 02 \quad 03}$

Lamb, M. E. (2010). The role of father in child development (5th ed.). New Jersey: John Wiley \& Sons, Ltd.

Levant, R. F., \& Powell, W. A. (2017). The gender role strain paradigm. In R. F. Levant \& Y. J. Wong (Ed.), The psychology of men and masculinities (hal. 15-44). Washington: American Psychological Association.

Lewin, A., Mitchell, S. J., Waters, D., Hodgkinson, S., Southammakosane, 
C., \& Gilmore, J. (2014). The protective effects of father involvement for infants of teen mothers with depressive symptoms. Maternal and Child Health Journal, 19(5), 1016-1023. doi: 10.1007/s10995-014-1600-2

Makpal, T. I., \& Adiyanti, M. G. (2016). Sikap terhadap peran gender dan efikasi diri paternal dalam memprediksi keterlibatan ayah pada pengasuhan anak usia dini di keluarga dual-earner. Universitas Gadjah Mada. Diambil dari http://etd.repository.ugm.ac.id/

Marsuq, A. F., \& Kristiana, I. F. (2017). Hubungan antara persepsi terhadap keterlibatan ayah dalam pengasuhan dengan konsep diri pada siswa kelas $\mathrm{X}$ SMK Negeri 4 Kendari. Jurnal Empati, 6(4), 247-253.

Maurer, T. W., \& Pleck, J. H. (2006). Fathers' caregiving and breadwinning: A gender congruence analysis. Psychology of Men and Masculinity, 7(2), 101-112. doi: 10.1037/1524-9220.7.2.101

McBride, B. A., Brown, G. L., Bost, K. K., Shin, N., Vaughn, B., \& Korth, B. (2005). Paternal identity, maternal gatekeeping, and father involvement. Family Relations, 54, 360-372. doi: 10.1111/j.1741-3729.2005.00323.x

McGill, B. S. (2014). Navigating new norms of involved fatherhood: Employment, fathering attitudes, and father involvement. Journal of Family Issues, 35(8), 1089-1106. doi: 10.1177/ $\underline{0192513 \times 14522247}$

Meteyer, K., \& Perry-Jenkins, M. (2010). Father involvement among workingclass, dual-earner couples. Fathering, 8(3), 379-403. doi: 10.3149/fth.0803.379

Palkovitz, R. (1997). Reconstructing "involvement": Expanding conceptualizations of men's caring in contemporary families. In A. J.
Hawkins \& D. C. Dollahite (Ed.), Generative fathering: Beyond deficit perspectives (hal. 200-216). Thousand Oaks, CA: Sage.

Palkovitz, R. (2002). Involved fathering and men's adult development: Provisional Balances. Mahwah, NJ: Lawrence Erlbaum Associates.

Partasari, W. D., Lentari, F. R. M., \& Priadi, M. A. G. (2018). Gambaran keterlibatan ayah dalam pengasuhan anak usia remaja (Usia 16-21 Tahun). Journal Psikogenesis, 5(2), 159-167. doi: 10.24854/jps.v5i2.504

Phares, V., Fields, S., \& Kamboukos, D. (2009). Fathers' and mothers' involvement with their adolescents. Journal of Child and Family Studies, 18(1), 1-9. doi: 10.1007/s10826-008$\underline{9200-7}$

Pleck, J. H., \& Hofferth, S. L. (2008). Mother involvement as an influence on father involvement with early adolescents. Fathering, 6(3), 267-286. doi: $\underline{10.3149 / \text { fth.0603.267 }}$

Pollack, W. S. (1995). No man is an island: Toward a new psychoanalytic psychology of men. In R. F. Levant \& W. S. Pollack (Ed.), A new psychology of men (hal. 33-67). New York: Basic Books.

Ramonetti, D. A. (2007). The impact of paternal involvement on maternal wellbeing and marital satisfaction. Doctoral Disertation. Hofstra University. Diunduh dari https://books.google.co.id/books/about The Impact of Paternal Involvemen $\mathrm{t}$ on Ma.html?id=OXdWNwAACAAI \&redir esc $=y$

Rohner, R. P., \& Veneziano, R. A. (2001). The importance of father love: History and contemporary evidence. Review of 
General Psychology, 5(4), 382-405. doi: 10.1037/1089-2680.5.4.382

Ryff, C. D. (1989). Happiness is everything, or is it? Explorations on the meaning of psychological well-being. Journal of Personality and Social Psychology, 57(6), 1069-1081. Diambil dari http://coursedelivery.org/write/wpcontent/uploads/2015/02/2-Happinessis-everything-or-is-it.pdf

Ryff, C. D., \& Keyes, C. L. M. (1995). The Structure of Psychological Well-Being Revisited. Journal of Personality and Social Psychology, 69(4), 719-727. doi: $\underline{10.1037 / 0022-3514.69 .4 .719}$

Santrock, J. W. (2015). Life-span development (15th ed.). New York: McGraw-Hill Education.

Saraff, A., \& Srivastava, H. C. (2010). Pattern and determinants of paternal involvement in childcare: An empirical investigation in a metropolis of India. Population Research and Policy Review, 29, 249-273. doi: 10.1007/ $\underline{\text { s11113-009-9139-4 }}$

Schindler, H. S. (2007). Becoming a father, father involvement, and father economic and psychological well-being. Boston College.

Schindler, H. S. (2010). The importance of parenting and financial contributions in promoting fathers' psychological health. Journal of Marriage and Family, 72(2), 318-332. doi: 10.1111/j.17413737.2010.00702.x

Schoppe-Sullivan, S. J., Brown, G. L., Cannon, E. A., Mangelsdorf, S. C., \& Sokolowski, M. S. (2008). Maternal gatekeeping, coparenting quality, and fathering behavior in families with infants. Journal of Family Psychology, 22(3), 389-398. doi: 10.1037/0893$\underline{3200.22 .3 .389}$
Septiani, D., \& Nasution, I. N. (2017). Peran keterlibatan ayah dalam pengasuhan bagi perkembangan kecerdasan moral anak. Jurnal Psikologi, 13(2), 120-125.

Sewaka, A. (2017). Komunitas ini isinya para ayah yang dukung ASI, yuk kenalan. Diambil 15 Januari 2018, dari https://www.haibunda.com/momslife/20171012151240-6811005/komunitas-ini-isinya-para-ayahyang-dukung-asi-yuk-kenalan

Simonelli, A., Parolin, M., Sacchi, C., De Palo, F., \& Vieno, A. (2016). The role of father involvement and marital satisfaction in the development of family interactive abilities: A multilevel approach. Frontiers in Psychology, 7, $1725 . \quad$ doi: $\underline{10.3389 / \text { fpsyg. } 2016.01725}$

Smith, J. A. (2009). The daddy shift. Massachusetts: Beacon Press.

Stolz, H. E., Barber, B. K., \& Olsen, J. A. (2005). Toward disentangling fathering and mothering: An assessment of relative importance. Journal of Marriage and Family, 67(4), 1076-1092. doi: 10.1111/j.1741$\underline{3737.2005 .00195 . x}$

Torres, N., Veríssimo, M., Monteiro, L., Ribeiro, O., \& Santos, A. J. (2014). Domains of father involvement, social competence and problem behavior in preschool children. Journal of Family Studies, 20(3), 188-203. doi: $\underline{10.1080 / 13229400.2014 .11082006}$

Wical, K. A., \& Doherty, W. J. (2005). How reliable are fathers' reports of involvement with their children: A methodological report. Fathering, 3(1), 81-91.

Wood, J. J., \& Repetti, R. L. (2004). What gets dad involved? A longitudinal study of change in parental child 
caregiving involvement. Journal of Family Psychology, 18(1), 237-249. doi: $\underline{10.1037 / 0893-3200.18 .1 .237}$

Zakiya, Z. (2018). Bapak Rangkul, komunitas suami modern yang berbagi peran pengasuhan anak. Diunduh pada 15 Januari 2018, dari https://www.vemale.com/keluarga/111 382-bapak-rangkul-komunitas-suamimodern-yang-berbagi-peranpengasuhan-anak.html.

Zuhairah \& Tatar, F. M. (2017). Hubungan antara keterlibatan ayah dalam pengasuhan dengan kenakalan remaja di kota Banda Aceh. Jurnal Pencerahan, 11(1), 46-52. 